\title{
Leadership of the Principal on Laboratory Elementary School of Unimuda Sorong in Improving the Quality of Education
}

\author{
Manut Pratikno \\ Universitas Pendidikan Muhammadiyah Sorong, Indonesia \\ Institut Agama Islam Negeri (IAIN) Sorong, 98417, Sorong, Indonesia \\ Email: mpratikno@unimudasorong.ac.id \\ Muhammad Rusdi Rasyid \\ Institut Agama Islam Negeri (IAIN) Sorong, 98417, Sorong, Indonesia \\ Email: mrrasyid@iainsorong.ac.id \\ Ismail Suardi Wekke \\ Institut Agama Islam Negeri (IAIN) Sorong, 98417, Sorong, Indonesia \\ The Jusuf Kalla Research Center for Bugis Makassar Cultural Studies, \\ Universitas Muslim Indonesia \\ iswekke@stainsorong.ac.id
}

\begin{abstract}
The purpose of this study was to analyze the role of the principal in improving the quality of education at the Laboratory Elementary School of Unimuda Sorong. The methodology used was qualitative with a phenomenological approach. The study found that the role of the principal in improving the quality of education at the Laboratory Elementary School of Unimuda Sorong consisted of three stages: input, processing, and output. The input stage includes 1) Free of costs: providing free education for Papuan children and 2) Mapping: prioritizing Papuan children and transmigrants' communities around the "Warmon Kokoda" village. The processing stage includes enlarging the classrooms, providing laboratories, creating a comfortable library for elementary school-aged children, evaluating alQur'an teachers, and daily controlling the Standard Operating Procedures (SOPs). Finally, at the output stage, all of the students of the past few years graduated with stable and static grades. The leadership style carried out by the principal was democratic in all respects by taking a social-persuasive approach when problems occur between teachers and parents and the surrounding community.
\end{abstract}

Keywords: Leadership, Principal, Quality, Elementary School.

\section{Introduction}

Quality education comes from qualified and professional principals who can manage and develop madrasas comprehensively. A principal has a critical and strategic role in realizing the vision, mission, and goals of the organization he leads (Wekke et al., 2017). Professional madrasah principals in carrying out their duties are full of quality improvement strategies to produce quality outputs and outcomes. The professionalism of the principal will show the quality of the madrasa's performance (Mulyoto, 2013).

Talking about the head of the madrasa will bring up a discussion about leadership. It is a very urgent thing a principal must have, as one of the substantial factors in an organization (Fadilah, 2021). An organization's success or failure is determined by the leadership of a leader in running the organization. Leadership emphasizes how a leader leads his organization. As stated by Prof. Imam Suprayogo, leadership is the process of influencing the activities of individuals or groups to achieve particular goals in a predetermined situation. In influencing individual activities, leaders use power, authority, influence, traits, and characteristics. The goal is to increase group productivity and morale (Suprayogo, 1999).

Mulyasa (2006) said, "a principal must be able to carry out his work, as an educator, manager, administrator, and supervisor (EMAS)." In developments adapted to the needs of the community and the times, school principals 
must also be able to act as leaders, innovators, motivators, and entrepreneurs in their schools. In the new paradigm of education management, principals must at least function as educators, managers, administrators, supervisors, and motivators (EMASLIM). School quality, as an indicator of productivity, is closely related to management problems in schools, as stated that "failure in an organization is caused by management weaknesses" (Rohiat, 2008).

In the implementation, many factors hinder madrasah principals from quality leadership due to their low performance (Wekke, 2018). The empirical experiences showed that, on average, madrasah principals lack academic ability, self-motivation, enthusiasm, and work discipline and have narrow insights. This phenomenon is due to the screening process that does not meet competence, lack of procedural, less transparent, and uncompetitive. Besides, the internal factors of the madrasah principals can be an obstacle to the growth and development of their professionalism. The low level of professionalism leads to low productivity in improving the quality of education (Rohiat, 2008).

Studies on the success of madrasah principals in leading school institutions showed that madrasah principals are the ones who determine the center point and rhythm of madrasas. The principals as the top leaders have the authority and power as well as effective leadership strategies to organize and develop their subordinates professionally. Furthermore, the studies concluded that the success of a madrasa depends on its principal. In this case, the principal is one of the components of education that plays the most role in improving the quality of education (Rivai, 2004). Thus, the principal is a professional or teacher who is given the task of leading a school where the school becomes a place of interaction between teachers who teach students who receive lessons, parents as expectations, graduate users as recipients of satisfaction, and the general public as pride (Bafaadal, 2010). 1992).

One of the explanation is how education run the school condition (Yusuf, Sabara, \& Wekke, 2019). Principals as educational leaders need to have future insight. According to Soebagio, educational leadership requires the main attention because, through good leadership, quality workers will be born in various fields as thinkers and workers who can ultimately improve quality human resources. The most important thing is that through education we prepare skilled, qualified, and ready-to-use personnel to meet the needs of business, industrial, and other communities (Atmadiwiryo, 2000).

Principals have three primary functions as follows: helping teachers understand, select, and formulate educational goals to achieve; mobilizing teachers, employees, students, and community members to succeed in school educational programs; and creating schools as a harmonious, healthy, dynamic, comfortable work environment so that all members can work with high productivity and obtain high job satisfaction (Kusmintarjo and Burhanuddin, 1997). These three functions show how important the function of the principal is as a caliph or ruler or leader to realize the nation's hopes and carry out the mandate and account for all of his leadership, including in moving school organizations.

As educators, principals must show a persuasive and exemplary attitude (Wahiosumidjo, 1999), which will color the leadership, including providing the teachers with guidance. Principals, as educators, supervisors, motivators, leaders, and innovators, must guide the employees and teachers because humans are the central factor that determines the entire movement of an organization's activities. No matter how sophisticated the technology used is, the human factor is still the determining factor.

As motivators, principals must encourage teachers to increase performance as the spearhead to create quality human beings. They will work optimally when supported by several factors, including the leadership of the principals. Works without motivation are boring with no motivation. Whether or not a leader, namely, in this case, a principal, is successful is determined by whether or not those he leads love him. In terms of the management of the principal of the Laboratory Elementary School, the under-expected conditions can also be caused by the conditions in which the students can not study well.

Such conditions, according to Andri Syamsul Rizal, are caused by four things, namely lack of motivation to learn, lack of active learning, moral decline, and lack of concentration in learning (Rizal, 2014). Lack of motivation to learn can lower the learning quality and ultimately result in low learning, including low values of piety or low morals of students. Creating an exciting learning atmosphere is necessary to strengthen students' learning motivation. Teachers can use various teaching methods: lectures, discussions, doing observations, and making and reading reports. Varying the learning methods is necessary because each student has different characteristics. It is also expected to generate students' learning motivation and prevent boredom. Among of the student skills in extending the recently conditions are $21^{\text {st }}$ century learning skills (Nasir Zakaria, Nawi, \& Wekke, 2019).

In improving the quality of education, all school members must have a united determination by optimizing school components and implementing management functions properly so that the education process occurs properly as well. A good process will produce good output as well. Therefore, the focus of this research was to determine the Leadership of the Principal of the Laboratory Elementary School of Unimuda Sorong in Improving the Quality of Education. 
Proceedings of the International Conference on Industrial Engineering and Operations Management Monterrey, Mexico, November 3-5, 2021

\section{Methods}

This study used a qualitative approach in which something studied is essential with a natural setting as the direct data source. Qualitative research has five characteristics: (1) Natural setting, (2) Descriptive, (3) Prominent process, (4) Inductive analysis, and (5) Disclosure of meaning. This research, based on this qualitative approach, used a phenomenological point of view, in which the researchers sought to understand the meaning of events and their correlation with ordinary people in certain situations.

Phenomenology does not assume that researchers know what things mean to the people they are studying. What is emphasized is the subjective aspect of people's behavior. They try to enter into the conceptual world of the subjects they study in such a way that they understand what and how an understanding is developed by them around events in everyday life (Moleong, 2000). The research location is at the Laboratory Elementary School of Unimuda Sorong, focusing on Principal Leadership in improving the quality of education.

\section{Results and Discussion 3.1 Principal Leadership}

The leader in an educational institution, in this case, a school or madrasa, is called the Principal (Suti et al, 2020), who is fully responsible for the good or bad of the institution being led. For this reason, every school principal has a strategy or method to improve his/her institution's quality. The Laboratory Elementary School of Unimuda Sorong is an educational institution devoted to Papuan children who live in Warmon Kokoda Village. It also serves transmigrants around the village who want to attend school. Mr. Bambang Irawan, S.Pd. is the Principal of the Laboratory Elementary School of Unimuda Sorong. He has only been leading the institution for four years, but he has brought the institution into a good institution and continues to improve the quality of education.

Several roles performed by Mr. Bambang Irawan, S.Pd. in improving the quality of education of the Laboratory Elementary School of Unimuda Sorong are:

1. Input Stage

The leader of the educational institution, namely the Principal, is really looking for the right strategy with the Unimuda Sorong Laboratory Elementary School environment. The principal divides this stage into several parts, namely the registration process, mapping test, graduation report cards, and announcements.

a. Registration Process

For the registration process for the 2019-2020 school year, the principal freed registration fees for all Prospective New Students of the Laboratory Elementary School of Unimuda Sorong, both Papuan and transmigrants' children, to attract parents to enroll their children.

b. Mapping Test

This mapping test process is a follow-up activity, instead of the selective test, after the New Student Registration Process (PPDB). In essence, the competency test is a selective test, but this mapping test focuses more on student competencies to sort out the competencies of new students according to their respective portions and to place them according to their respective abilities.

Things that are also considered in this mapping test include the distance of the prospective student's house from the Laboratory of Elementary School of Unimuda Sorong. A distance of 0-1 km from school gets a score of 50, that of $1-3 \mathrm{~km}$ gets 40 , that of $3-5 \mathrm{~km}$ gets 30 , while that of $5 \mathrm{~km}$ and above gets 20 . Certificates of appreciation and supporting certificates will also be a reference for prospective students to have the opportunity to be accepted at the Laboratory Elementary School of Unimuda Sorong.

2. Processing

The principal is constantly making improvements in terms of facilities and infrastructure at the Laboratory Elementary School of Unimuda Sorong. Currently, what is being focused on is the construction of new classrooms. Previously, the Laboratory Elementary School of Unimuda Sorong had made improvements to learning support facilities, such as (a) enlarging classrooms, (b) providing computer laboratories for science and technology, (c) providing language laboratories to hone children's foreign language skills, especially Arabic and English, (d) providing mosques in the school environment, and (e) providing library room as a support for learning and others.

All of these are a manifestation of the Principal's commitment to improving the quality of education at the Laboratory Elementary School of Unimuda Sorong. Apart from the things above, the school will continue to monitor students' skills in reading and writing the Qur'an. The students are tested regularly in terms of whether or not they are fluent in reading the Qur'an. Those considered having not met the standards set by the school or, more precisely, are not very good at reading and writing the Qur'an must follow intensive guidance through the Qur'an reading clinic program supported by a good method, namely the UMMI method. 
Proceedings of the International Conference on Industrial Engineering and Operations Management Monterrey, Mexico, November 3-5, 2021

\section{Output}

The principal said that after a 6-year learning process, students of the Laboratory Elementary School of Unimuda Sorong can take the final exam. Over the past few years, all students of the Laboratory Elementary School of Unimuda Sorong $(100 \%)$ have graduated. However, the output is still stable or static as shown by the results of UNAS (National Examination) or now better known as UASBN/UAMBN (National Standard of School/Madrasah Final Examination).

The school's strategy to prepare students for exams such as UNAS and others is to conduct intensive coaching every morning and evening, including additional tutoring, in addition to the regular teaching and learning activities. This strategy is expected to also help improve the quality of education at the Laboratory Elementary School of Unimuda Sorong.

Apart from the three measures of education quality above, the Principal, namely Bambang Irawan, S.Pd., is also aggressively fixing schools comprehensively to obtain the legality under the ISO (International Organization for Standardization) system. According to him, the ISO system has two main principles, namely "do what you write and write what you have done." That is, in an institution, we must first prepare a guideline as a basis before making programs to make our works effective and efficient. Standardized ISO tests include the following: Organizational Structure, Management Guidelines or Rules, Standard Operating Procedures (SOP) of 2019, in which Bambang Irawan, S.Pd. had his third year. According to him, the quality development of the Laboratory Elementary School of Unimuda Sorong requires clear standardization. Therefore, for the first time, he checked the "ground standard" (basic conditions before the principal entered). If you already know the initial conditions, it will be easy for us to improve the quality. Therefore, it is necessary to take several strategic steps, namely (1) making a mapping; (2) creating guidelines or ground rules; (3) scheduling or planning works (work program); (4) making SOP (Standard Operating Procedures); (5) after a comprehensive check, the first thing targetted by the Principal is the school's organizational structure which includes the Head of Administration, Deputy Principals (2 people), and Financial Controllers (2 people). On the other hand, the principal also makes a structure for class teachers which did not exist in the previous management. This is because each homeroom teacher has different standards for students.

In addition to providing strategic steps to improve the quality and quantity of teachers, the Principal also provides a budget for the Administration department, namely for the training of the teacher council and departmental staff who are usually assigned to other agencies or institutions to conduct comparative studies. According to the results of an interview with the deputy head of student affairs, there are several strategies from the Head of Madrasah, as follows:

1. In making a policy, the principal usually holds a management meeting to discuss with the management. The results are conveyed to the teacher council, employees, and even students' parents through subsequent meetings.

2. Management meetings are usually held continuously every Tuesday, while meetings with the teacher and employee councils are done every two weeks on Saturday.

3. The principal always targets his students to win in competitions, science olympiads, or others on a national scale. For this reason, he often invites national-level olympiad trainers. This does not mean that the principal does not entrust the guidance of the Laboratory Elementary School of Unimuda Sorong teacher council but, rather, because there are no teachers who have mentored for olympiads at the national level.

After the basic conditions have been detected and the preparation of human resources has also been carried out, the principal plans a work program with the teachers and employees by involving the school committee since he assumes that work programs are related to the school's community resources.

The principal always supervises the implementation of all the strategies set to ensure that everything goes based on the plan. Therefore, School Self-Evaluations are often held, involving all existing stakeholders, even gardeners.

\subsection{The Principal's Leadership Style}

Three types of leadership that can be applied by a principal, as follows: a. Autocratic/Authoritarian Type

Autocracy comes from the words oto, which means self, and kratos, which means government. So, autocracy means being government and having self-determination. Autocracy depicts a government in which someone has full power for an unlimited period of time. The holder of power is called an autocrat who is usually a leader being a king or using a royal system. In the context of the school environment, a principal having such kind of style will have absolute and central power in determining school policy. In simple terms, this type of autocracy is not appropriate to be applied in the world of education because criticism, suggestions, and opinions of others are necessary to improve the quality of education.

b. Laissez-Fair Type 
Proceedings of the International Conference on Industrial Engineering and Operations Management Monterrey, Mexico, November 3-5, 2021

A principal with the laissez-faire leadership type wants all components of education actors to carry out their duties freely. Therefore, a principal applying this type must have the ability to influence others to be willing to work together to achieve the goals set by means of various activities assigned to subordinates. Because the literal meanings of lassez and faire are to allow and to be free, respectively, so the meaning of laissez-faire is to provide others with the principle of freedom. Subordinates are allowed to carry out their duties freely. This type is applicable in schools that really have good human and natural resources and are able to design all their needs independently.

This laissez-faire leadership type, in the context of Indonesian education, is very difficult to implement for several obstacles faced, ranging from problems of funding, human resources, independence, and others. In this type of leadership, each group should moves independently so that all aspects of leadership cannot be realized and developed. According to Imam Suprayogo, this type of leadership is very suitable for people who are really mature and really know what the common goals are to be achieved (Townsend, 1992).

c. Democratic Type

Democratic leadership is leadership based on democracy, whose implementation is called participatory leadership. Participatory leadership is the way taken by a leader whose strength lies in the active participation of every member of the group. A principal who applies this type of leadership considers himself part of a group of school actors, parents, and the general public, so he does not always make his own decisions and policies, but through deliberation and consensus. As stated in the Qur'an, meaning "And those who have responded to their Lord and established prayer and whose affair is [determined by] consultation among themselves, and from what We have provided them, they spend, (QS. Asy-Syuura: 38)

A leader in education cannot be said to have democratic characteristics if his/her activities and the resulting work situation do not clearly demonstrate the application of leadership principles which include participation, cooperatives, close human relations, delegation and distribution of power and responsibility, organizational and work procedures flexibility, and creativity.

This research at the Laboratory Elementary School of Unimuda Sorong found the type or style of leadership applied by the principal in improving the quality of education. According to the narratives of education staff, teachers, administration staff, and deputy heads, Bambang Irawan, S.Pd. is very democratic in all respects, open to every problem, always pays attention to his subordinates, and others, as explained in more detail below.

First, the interview with the Deputy Head of Public Relations about some of the principal's attitudes shows how the leadership style applied by the principal is. The principal always pays attention to inputs, suggestions, and criticism, showing that he is not an authoritarian. He also behaves well in social life and supports every madrasa activity. He is different from the former, who was authoritarian.

Secondly, in line with the Deputy Head of Public Relations, the Deputy Head of Student Affairs stated that he was very democratic in any matter. He takes a social approach so that all parties feel valuable in giving opinions. Every policy, like making student rules, is always discussed first through a management meeting before being socialized in teacher and guardian meetings. The principal is also a perfectionist, so every policy that has been agreed upon must be completed neatly, nicely, and on time. This attitude makes some like him and some don't. There is only one negative thing others see from the principal: he is attending the school rarely because he's busy teaching outside of his position as principal.

The Deputy Head of Student Affairs added that there were several weaknesses in the leadership of Mr. Bambang Irawan, S.Pd, namely the lack of time for school, making it very difficult to conduct deliberations. However, the school is aware of his busyness; he is also a teacher at the Laboratory Elementary School of Unimuda Sorong.

Thirdly, the Head of Administration stated that the principal in determining a policy is usually based on his own concept. However, if the policy to be taken is related to complaints and a program, then he conducts deliberation because he does not want to take risks if his decision can harm the madrasa he leads. The head of administration also said that the principal is a democratic leader.

\subsection{Findings and Analysis}

The researchers found several things that indicated an increase in the quality of education at the Laboratory Elementary School of Unimuda Sorong. Based on several theories of the definition of quality and its substance in education, the researchers would describe and compare leadership strategies with improving the quality of education. In the context of education, the notion of quality includes educational inputs, processes, and outputs. Educational inputs include everything that must be available because it is needed for the process to take place. Educational processes mean changing something into something else by integrating school inputs to create a pleasant learning situation encouraging the students to have motivation and interest in learning, thus empowering them. Educational outputs mean the school's performance which is measurable by its quality, effectiveness, productivity, efficiency, innovation, and work morale. 
Proceedings of the International Conference on Industrial Engineering and Operations Management Monterrey, Mexico, November 3-5, 2021

Townsend and Butterworth (1992) state on their book entitle Your Child's School, there are ten determinants of the realization of a quality educational process, namely the effectiveness of the principal's leadership; participation and sense of responsibility of teachers and staff; effective teaching and learning process; programmed development of staff; relevant curriculum; clear vision and mission; conducive school climate; self-assessment of strengths and weaknesses; effective internal and external communication; and intrinsic parental and community involvement. Quality of education refers to the quality of products produced by educational institutions or schools (Townsend, 1992). This condition lead to inclusive education (Mujahid, Minsih, Ghafur, \& Wekke, 2019).

Hari Sudradjad stated that quality education is education that is able to produce graduates who have the ability or competence, both academic and vocational competencies, which are based on personal and social competencies, as well as noble moral values, all of which are life skills. Sudradjat further stated that quality education is education that is able to produce complete human beings with integral personalities, namely those who are able to integrate faith, knowledge, and charity.

Edward Salis argued that there are many sources of quality in education, such as good building facilities, outstanding teachers, high moral values, satisfactory exam results, specialization or vocational training, encouragement from parents, local businesses and communities, abundant resources, application of the latest technology, good and effective leadership, attention to students' lessons, and proper curriculum, or a combination of these factors. Quality in the field of education includes the quality of inputs, processes, outputs, and outcomes. Educational inputs are declared qualified if they are ready to process. A quality education process can create a PAKEM (Active, Creative, and Fun Learning) atmosphere. Inputs include teaching materials (cognitive, affective, or psychomotor), methodology (which varies according to the ability of the teacher), facilities, administrative support and infrastructure and other resources as well as creating a conducive atmosphere. In addition, there are the presences of information and communication technology (Idris, Willya, Wekke, \& Mokodenseho, 2020).

From the explanation above, the principal was found to have implemented the theories, as shown by the results of the study, namely:

a. Input Stage

The leader of the educational institution, namely the principal, is looking for the right strategy in the Laboratory Elementary School of Unimuda Sorong by dividing the input stage into several parts, namely the registration process, mapping test, graduation report cards, and announcements. He also does not stop making improvements in terms of facilities and infrastructure in schools. Today he focuses on constructing new classrooms due to the increasing number of enthusiasts who want to study in Warmon Kokoda Village.

Previously, the Laboratory Elementary School of Unimuda Sorong has also made improvements to learning support facilities by (1) enlarging classrooms, (2) providing a computer laboratory for science and technology, (3) providing a language laboratory to hone the children language skills, especially Arabic and English, (4) providing a mosque, and (5) providing a library room as a support for learning and others. Those all five facilities will contribute to extend the possibilities for quality education.

All of these are the manifestation of the principal's commitment to improving the quality of education at the Laboratory Elementary School of Unimuda Sorong. Besides, the school is continuing to monitor the students' Qur'an reading and writing skills. The students are tested regularly about whether or not they are fluent in reading the Qur'an. Those considered do not meet the standards set by the school must follow intensive guidance through an al-Qur'an reading clinic program supported by a good method: UMMI. However, this school is multicultural education-based activities. The presence of Quran as the main source to drive the spirit of the school (Yusuf, Nahdhiyah, \& Wekke, 2019).

b. Output Stage

The principal revealed that after a 6-year learning process, students of the Laboratory Elementary School of Unimuda Sorong can take the final exam. Over the past few years, all students of the Laboratory Elementary School of Unimuda Sorong (100\%) have graduated. However, the output is still stable or static as shown by the results of UNAS (National Examination) or now better known as UASBN/UAMBN (National Standard of School/Madrasah Final Examination). The school's strategy to prepare students for exams such as UNAS and others is to conduct intensive coaching every morning and evening, including additional tutoring, in addition to the regular teaching and learning activities. This strategy is expected to help improve the quality of education at the Laboratory Elementary School of Unimuda Sorong.

\section{Conclusion}

From the research conducted at the Laboratory Elementary School of Unimuda Sorong regarding the leadership of a principal in improving the educational quality of the institution, it can be concluded that the principal has (a) provided good service to the community by freeing new students of the registration fee, (b) providing directions for 
Proceedings of the International Conference on Industrial Engineering and Operations Management Monterrey, Mexico, November 3-5, 2021

carrying out a mapping test for prospective new students so that the school really knows the capacity of their new prospective students and prepare the right formula for each student, (c) relating to the learning process and school activities, prepared properly all existing elements, namely all human resource it has, be it the teacher council, employees, administration, gardeners, and security staff, and (d) in terms of infrastructure, provided several learning support facilities, namely the existence of a library, computer laboratory, language laboratory, comfortable classrooms, and places of worship. In terms of output, (e) the Laboratory Elementary School of Unimuda Sorong always succeeds in making $100 \%$ of its students pass each year due to the maturity of the Laboratory Elementary School of Unimuda Sorong, which has been prepared during the learning process or activity.

The principal has shown several strategies that can improve the quality of education at the Laboratory Elementary School of Unimuda Sorong, namely by (a) dividing the input stage into the registration process, mapping test, and graduation report cards, (b) making strategies in preparing the learning process as effective as possible, (c) for several years, having always succeeded in graduating all of the students. However, so far, the output is still stable or static. The school's strategy to prepare students for exams such as UNAS and others is to conduct intensive coaching every morning and evening, including additional tutoring, in addition to the regular teaching and learning activities. This strategy is expected to help improve the quality of education at the Laboratory Elementary School of Unimuda Sorong.

\section{References}

Anakotta, R., Alman A., \& Solehun S. (2019). "Akulturasi Masyarakat Lokal dan Pendatang di Papua Barat." Jurnal Antropologi: Isu-Isu Sosial Budaya 21(1), 29-37.

Atmadiwiryo, S. (2000). Manajemen Pendidikan Indonesia. Jakarta: Ardadirya.

Bafaadal, I. (1992). Supervisi Pengajran: Teori dan Aplikasi Dalam Membina Profesional Guru. Jakarta: PT. Bumi Aksara,

Fadilah, A. N. (2021). Dinamika pendidikan agama islam pada masyarakat Suku Kokoda di Kabupaten Sorong. Diss. UIN Sunan Ampel Surabaya.

Idris, M., Willya, E., Wekke, I. S., \& Mokodenseho, S. (2020). Peace resolution in education and application on information and communication technologhy. International Journal of Advanced Science and Technology, 29(6), 3349-3358.

Kusmintarjo, K., \& Burhanuddin, B. (1997). Kepemimpinan Pendidikan Bagi Kepala Madrasah. Jakarta.

Moleong, L. J. (2000). Metode Penelitian kualitatif. Bandung: Remaja Rosdakarya.

Mujahid, I., Minsih, M., Ghafur, W. A., \& Wekke, I. S. (2019). Teaching and learning in inclusive classroom; case in elementary school. Journal of Advanced Research in Dynamical and Control Systems, 11(8 Special Issue), 557-568.

Mulyasa, M. (2006). Menjadi Kepala Sekolah Professional. Bandung: PT. Raja Grafindo.

Mulyoto, dkk. Kepemimpinan Kepala Madrasah Dalam Meningkatkan Mutu Madrasah (Studi Kasus Tentang Manajemen Kepala Madrasah Tsanawiyah Negeri Bendosari Sukoharjo), Jurnal Teknologi Pendidikan, Vol 1, No 2, (2013), 199-213.

Nasir Zakaria, G. A., Nawi, A., \& Wekke, I. S. (2019). The effectiveness of implementing noble values through online problem-based learningamong students in higher learning institution. Journal of Advanced Research in Dynamical and Control Systems, 11(8 Special Issue), 540-556.

Rivai, Vaitzal. (2004). Memimpin Dalam Abad ke-21. Jakarta: PT. Raja Grafindo Persada.

Rizal, Andri Syamsul. (2014). Inovasi Pembelajaran Pendidikan Agama Islam. Bandung: Kuala Press.

Rohiat. (2008). Kecerdasan Kepemimpinan Kepala Sekolah. Bandung: PT Refika Aditama.

Suprayogo, Imam. (1999). Revormulasi Visi Pendidikan Islam. Malang: STAIN Press.

Suti, Marsus, Muh Zadly Syahdi, \& D. Didiharyono. "Tata Kelola Perguruan Tinggi dalam Era Teknologi Informasi dan Digitalisasi." JEMMA (Journal of Economic, Management and Accounting) 3.2 (2020): 203-214.

Townsend, Diana \& Butterworth (1992). Your Child's Scholl. New York. A Plime Book.

Wahiosumidjo. Kepemimpinan Kepala Madrasah. Jakarta : PT Raia Grafindo Persada-1999.

Wekke, I. S. Pesantren, Madrasah, Sekolah, Dan Panti Asuhan: Potret Lembaga Pendidikan Islam Minoritas Muslim. At-Tajdid: Jurnal Ilmu Tarbiyah, 6.1 (2018): 128-144.

Wekke, I. S., Rubawati, E., \& Nurjannah, S. (2017). Kepemimpinan Transformatif di Madrasah Minoritas Muslim Papua Barat. J-MPI (Jurnal Manajemen Pendidikan Islam), 2(1), 1-10.

Yusuf, M., Nahdhiyah, N., \& Wekke, I. S. (2019). Dimension of Human Perfection Based on the Quran. Opción, 35(89), 402-418.

Yusuf, M., Sabara, Z., \& Wekke, I. S. (2019). Role of innovation in testing environment kuznets curve: a case of Indonesian economy. International Journal of Energy Economics and Policy, 9(1), 276. 
Proceedings of the International Conference on Industrial Engineering and Operations Management Monterrey, Mexico, November 3-5, 2021

\section{Biographies}

Manut Pratikno is student at Postgraduate Program of Institut Agama Islam Negeri (IAIN) Sorong, West Papua, Indonesia. He is the faculty member of Universitas Pendidikan Muhammadiyah Sorong, West Papua, Indonesia. Among his activities are Muhammadiyah of Regional Leadership, West Papua.

Muhammad Rusdi Rasyid is an Assistant Professor in the Postgraduate Program of Institut Agama Islam Negeri (IAIN) Sorong, West Papua, Indonesia. He joined the doctoral program of Universitas Islam negeri Alauddin Makassar, South Sulawesi, Indonesia.

Ismail Suardi Wekke is an Assistant Professor in the Postgraduate Program of Institut Agama Islam Negeri (IAIN) Sorong, West Papua, Indonesia. He earned his Ph.D. in the Faculty of Education in Universiti Kebangsaan Malaysia under Ford Foundation International Fellowship Program. 